\title{
TECHNOLOGY ORIENTATION AND EFFECTUATION - LINKS TO FIRM PERFORMANCE IN THE RENEWABLE ENERGY SECTOR OF SOUTH AFRICA
}

\author{
B. Urban ${ }^{1 *}$ \& J. Heydenrych ${ }^{2}$ \\ Graduate School of Business Administration \\ University of the Witwatersrand \\ Johannesburg, South Africa \\ ${ }^{1}$ boris.urban@wits.ac.za, ${ }^{2}$ jamesh@wits.ac.za
}

\begin{abstract}
Effectuation processes are consistent with emergent or non-predictive strategies, and speak to the essence of Schumpeter's theory of creative destruction. In this study, hypotheses are formulated to understand the relationship between effectuation, technology orientation, and firm performance. The study takes place in South Africa, which remains a highly significant economic player in sub-Saharan Africa, and is focused on the renewable energy sector. Survey results provide evidence that different dimensions of effectuation are positively associated with technology orientation, and influence firm performance. Policy makers should be encouraging firms to use effectual principles of experimentation, flexibility, establishing pre-commitments, and forming alliances, so as to maximise their returns on technology and constrain their potential losses.
\end{abstract}

\section{OPSOMMING}

Totstandbringprosesse is kenmerkend van ontluikende- of nie-voorspellende strategieë en wys op die wese van Schumpeter se teorie van kreatiewe vernietiging. In hierdie studie word hipoteses geformuleer om die verwantskap tussen totstandbrenging, tegnologie oriëntasie en firma vertoning te verstaan. Die studie vind plaas in Suid-Afrika, wat steeds ' $n$ beduidende ekonomiese rol in sub-Sahara Afrika speel, en is gefokus op die hernubare energie sektor. Opname resultate bewys dat verskillende dimensies van totstandbrenging positief geassosieer word met tegnologie oriëntasie en dat dit firma vertoning beïnvloed. Beleidmakers moet firmas aanmoedig om die totstandbrengings-beginsels van eksperimentasie, buigsaamheid, die daarstelling van vooraf verpligtinge en die vorm van genootskappe, te gebruik om sodoende hul opbrengste uit tegnologie te maksimeer en hul potensiële verliese te beperk.

Corresponding author 
Technology plays a significant role in stimulating innovation in firms, and encourages the development, diffusion, adoption, and application of the very latest business practices. This is particularly relevant in emerging economies where there is great potential for firms to import and adapt technologies developed in industrialised countries [44]. For firms in emerging markets the rising trend towards globalisation presents multiple opportunities to adopt a technology posture or orientation that can provide the necessary competitive advantage to compete globally [43].

Firms that have adopted a technology orientation (TO) pursue advances in technology and innovations, and investments are made in discontinuous innovations and disruptive technologies on the assumption that entirely new markets will emerge $[6,38]$. TO can be viewed from a strategic perspective that can guide the development and use of technological capabilities in a firm $[9,14]$, and where search practices, exploration activities, and firm performance have been shown to improve innovations in a firm [2]. Moreover, TO has been linked to entrepreneurial orientation (EO) at the firm level, and this in turn has been linked with increased innovativeness and firm performance $[3,10,34,49,50]$.

However, technology is characterised by its high degree of uncertainty, shown in aspects such as the level of output generated, the time in which these returns are produced, and the specific area of application. Additionally, even though firms create technologies, rival firms might readily exploit these technologies, with the consequence that no benefits are harvested by TO firms [43]. There is even uncertainty about whether the results expected from the technology investment will really be achieved [19]. These difficulties surrounding the adoption and effective use of technology have highlighted the importance of uncertainty and the relevance of non-predictive strategy, with numerous researchers questioning the utility of emphasising prediction and/or adapting to exogenously-given circumstances [45]. Initially, both Simon [40] and March [25] argued that a 'technology of foolishness', which is largely non-analytical and non-prophetic, could be beneficial for a firm. More recently, Sarasvathy [35] has shown how expert entrepreneurs use an effectual logic that is non-predictive to fashion new markets and transform environments. Whereas predictive strategies are ways to influence current realities to reach preconceived ends, effectual strategies spawn unique goals and new worlds from current realities [35,36].

The effectuation logic is particularly suitable for forming an empirical basis in the TO context, since both entrepreneurs and decision-makers in these situations face high levels of uncertainty [15]. Research shows how large companies have difficulties in executing innovative strategies, and suggest that an effectual approach would be beneficial [6]. As the field of effectuation research is only now progressing towards an intermediate phase [29], few quantitative studies have been performed to investigate causal links between effectuation and other established constructs such as technology and firm performance. The present study is able to fill this gap and to add empirically-grounded theoretical insights to the discourse on effectuation, which - since its initial delineation by Sarasvathy [35] - has been of a conceptual and qualitative nature (e.g., [18]).

By contextualising the study's findings in an emerging market context - South Africa - and an emerging sector - renewable energy (RE) - it is anticipated not only that insights will materialise, but also that the study will allow researchers to compare and examine the constructs used in this study and their proposed relationships in similar environmental and industry contexts. Managers, corporate entrepreneurs, and multiple stakeholders in the RE sector will benefit long-term from this study. The rest of the article is structured as follows. First, theoretical foundations are scrutinised to provide a basis for the hypotheses. Next, the research methodology is explained in terms of sampling and instruments used. This is followed by hypotheses testing, with a discussion of the results and implications. The 
article ends by mentioning the study's limitations, avenues for future research, and contributions made.

\section{THEORETICAL OVERVIEW AND HYPOTHESES FORMULATION}

\subsection{Effectuation}

Effectuation processes are consistent with emergent [26] or non-predictive strategies [48], and speak to the essence of Schumpeter's [39] theory of creative destruction. Sarasvathy [35] defines effectuation as a process that "takes a set of means as given and focuses on selecting between possible effects that can be created with that set of means". Effectuation is a means-driven process that enables the entrepreneur or firm to exercise control over its environment and thus its future. Causation processes, conversely, are concerned with the strategic positioning of the organisation within an exogenous environment [29].

In her seminal work, Sarasvathy [35] developed five behavioural principles that relate to effectuation and causation: (1) beginning with a given goal or a set of given means; (2) focusing on expected returns or affordable loss; (3) emphasising competitive analysis or strategic alliances and pre-commitments; (4) exploiting pre-existing knowledge or leveraging environmental contingencies; and (5) trying to predict a risky future or seeking to control an unpredictable future. Based on these principles individuals using effectual logic will begin with a given set of means, focus on affordable loss, emphasise strategic alliances, exploit contingencies, and seek to control an unpredictable future. By contrast, an individual using causal logic will begin with a given goal, focus on expected returns, emphasise competitive analyses, exploit pre-existing knowledge, and try to predict an uncertain future $[29,37]$. Recognising the five behavioural principles related to effectuation and causation, Chandler et al. [8] proposed that effectuation might be viewed as a formative and multidimensional construct composed of the following sub-constructs: (1) affordable loss, (2) experimentation, (3) flexibility, and (4) pre-commitment. These subconstructs are briefly explained:

(1) Affordable loss entails managers deciding what they are willing to risk by following a particular strategy [16]. In other words, managers evaluate an investment according to whether the business could absorb the loss from the total failure of a venture.

(2) Experimentation has been conceptualised as a series of trial-and-error changes pursued along various dimensions of strategy, over a relatively short period of time, in order to develop a competitive advantage [37].

(3) The third dimension specifies that effectuators tend to remain flexible, since the structure of the emerging organisation is dependent on contingent opportunities and the particular investments made by the stakeholders. Thus the need for prediction is greatly reduced [35].

(4) The last dimension is concerned with establishing pre-commitments and alliances with customers, suppliers, and other strategic partners that help to reduce uncertainty. By diversifying risk among multiple stakeholders, the effectuator is able to constrain potential losses, making it more affordable [35].

These sub-constructs of effectuation offer guidelines for decision-makers in firms focused on technology and innovation. Recently researchers have started using effectuation to study innovation and $R \& D$ performance in a corporate setting [6].

\subsection{Technology-orientation}

The essence of Schumpeter's [39] theory of creative destruction is that entrepreneurs distort the market equilibrium by introducing new product-market combinations or innovations. Radical innovation lies at the core of new business development and long-term wealth creation [38,45]. Technological innovativeness is related to novelty in the required technological expertise and the application of this new technological expertise. Developing new product technology and a concern for technical expertise and creativity demonstrate 
the importance for technology-based ventures to select strategies that they can successfully execute [38,42].

The technological choices of a firm are usually clarified in its technology strategy - i.e., the plan that guides the accumulation and deployment of technological resources and capabilities [50]. When a fit between a firm's strategic and technological choices is achieved, the firm can employ its technological investments and capabilities to create a competitive advantage that supports its strategic goals and posture $[4,20,23]$.

Zahra and Covin [52] conceptualise TO as the set of organisational decisions concerning (1) aggressive technological posture, (2) automation and process innovation, and (3)new product development. Zahra [51] goes on to operationalise TO in terms of the following dimensions:

- $\quad$ Pioneering posture:Where a venture decides whether or not to be among the industry's first firms to introduce new products (technologies) to the market (and the number of products introduced).

- Internal vs. external R \& D sources:Were 'internal sources' refers to in-house R \& D activities, while 'external sources' includes purchasing or licensing of technology from other firms, or joining strategic alliances to acquire that technology (and includes the level of $R$ \& $D$ spending).

- $\quad$ Applied vs. basic research:Where basic $R \& D$ advances science, while applied $R \& D$ leads to new products and technologies.

- The venture's use of patenting to protect any competitive advantages it might gain from its $R \& D$ activities.

Furthermore, whereas most existing frameworks on technology-strategy fit assume that exogenous factors drive the $R \& D$ process, Brettel et al. [6] posit that human action and the organisation are at the centre of the process, thereby acknowledging that control can be actively built using effectual elements. Research confirms that a means-driven approach has a positive impact on R \& D project outputs, particularly in projects with high levels of innovativeness [6]. Technology and innovativeness can lead to the development of new organisational competences through the process of trial-and-error and creativity [1], which mirrors the principles of effectuation. Consequently, by bringing together the technology and effectuation literatures and considering the evolving nature of the effectuation field [29], it is initially hypothesised, at the higher-level order of constructs, that:

Null hypothesis: There is norelationship between effectuation and TO at the firm level.

\subsection{Effectuation and firm performance}

Even though much of the existing literature $[16,35,48]$ has been of a conceptual nature in attempting to establish the dimensions and heuristics of effectuation, the impact of effectuation on firm performance is being increasingly studied. In this regard, Read, Song and Smit [32] employ meta-analysis to detect variables that reflect the sub-constructs of effectuation and determine their influence on firm performance. They report mixed yet positive and significant relationships between firm performance and several dimensions of effectuation.

Although there is no consensus on the effectuation-performance relationship, nor is there agreement on an appropriate measure of firm performance, researchers have pointed to the multidimensional nature of performance as the crucial indicator of firm success [12]. Following the literature on the evolving nature of and the different methods used for assessing firm performance and viewing effectuation as a multidimensional construct composed of four sub-constructs [8], it is hypothesised that:

Null Hypothesis 2a: The effectuation dimension of experimentation will not have an influence on the firm's level of performance. 
Null Hypothesis $2 \mathrm{~b}$ : The effectuation dimension of affordable loss will not have an influence on the firm's level of performance.

Null Hypothesis 2c: The effectuation dimension of pre-commitment will not have an influence on the firm's level of performance.

Null Hypothesis $2 \mathrm{~d}$ : The effectuation dimension of flexibility will not have an influence on the firm's level of performance.

\section{RESEARCH METHODOLOGY}

The firm was selected as the appropriate level of analysis for this study, as it represents an aggregate of different individuals and business activities. As a result, the unit of analysis was the chief executive officer (CEO) or head of business development. In essence, what was really being measured was the manager's self-perception, which serves as a relevant proxy of the TO and levels of effectuation of the firm [46].

\subsection{Sampling}

The targeted population for this study was firms operating in the RE sector in South Africa. Firms in other high-growth, high-technology industries were deliberately excluded in order to minimise the moderating effects of the industry environment. By focusing on a single industry sector, a greater homogeneity of context is achieved that addresses the concerns of broad applicability versus perfect suitability for narrower groups [13]. Studies across industries often produce results that apply to all, while at the same time they apply to none. Consequently the focus was on a single industry.

The RE sector in South Africa is still to some extent in its inception phase, so no exhaustive database of firms active in this industry was available. Nonetheless, a sampling frame was obtained from the Sustainable Energy Society of South Africa (SESSA), from which a total of 423 closed questionnaires were sent out to member firms involved in the RE businesses.

A research design involving a web-based self-reporting survey instrument was used. The survey was distributed electronically, and was selected principally because of its functionality and (more importantly)because it was considered suitable for the target population, who were likely to use online resources regularly. Respondents were contacted with periodic reminder calls and emails in order to facilitate a high response rate. Despite these efforts, only 73 complete responses were received, which served as the final sample (a 17 per cent response rate). To test for non-response bias, archival and secondary sources were used and compared with non-responding firms. Results of t-tests comparing these firms with the current study sample's mean scores on selected effectuation variables revealed no differences $(p>0.10)$, suggesting that the sample was representative of the population on which it was based [11].

\subsection{Research instrument}

The survey instrument was developed from past theory and empirical findings, which coincide with the main constructs under investigation. These include:

Effectuation: The measurement instrument for the effectuation construct was based on a past exploratory and confirmatory factor analysis conducted by Chandler et al. [8], where effectuation was treated as a formative multidimensional construct with the four associated sub-dimensions (as discussed in the literature review section). The subconstructs of experimentation, affordable loss, pre-commitments, and flexibility were all measured along a seven-point Likert scale.

TO: This measure was based on Zahra's [51] operationalisation of TO with the following dimensions: Pioneering posture, number of products to be introduced to the market, internal vs external $R \& D$ sources, level of $R \& D$ spending, applied vs basic research, and 
the venture's use of patenting. Each dimension was measured with several items along a seven-point Likert scale.

Firm performance: Firm performance was measured using subjective, self-reported measures of performance, which is consistent with past research where a managers' perceptions of the performance of their firm is highly consistent with how the firm actually performed as indicated by objective measures [31]. Adopting similar indicators, respondents were asked to rate their firm performance - using a seven-point Likert scale relative to that of their competitors and benchmarked against their own expectations over a fixed period of time. Following Wiklund and Shepherd [47], these performance measures were standardised and then combined to reflect a global performance index.

Additional variables were included as control variables, based on past findings, indicating the importance of their inclusion [9]. Firm age was processed into two categories of younger and older firms. Firm size was processed using principal component analysis and then categorised into two sets as 'smaller and larger firms'. Additionally, entrepreneurial experience was accounted for, as it has been shown to be a predictor of firm success, and also explains variance in entrepreneurial performance [31].

Reverse coding of several scale items was performed in anticipation of acquiescence response set bias. The basic logic here is that reverse-coded items act like cognitive 'speed bumps' that require respondents to engage in more controlled (rather than automatic) cognitive processing [30]. As a precaution, common method response bias was controlled for by ensuring that the questions relating to the dependent variables were located away from the independent and moderator variables in the instrument. Moreover, with the $a$ priori inclusion of compelling theory where, in some instances, there is already evidence for discriminant and convergent validity of measures [8]. Where the performance indicators have been shown to have acceptable criterion-related validity using a range of both categorical and continuous criterion variables [41], only the reliability of these scales was tested for this sample of respondents. Furthermore, in terms of the ratio of respondents to the number of questionnaire items used in the survey, it was deemed insufficient to test the factor structure of these scales [22]. Internal consistency was assessed and item statistics were calculated for each of the scales, with the Cronbach alpha coefficients reported in Table 1, all of which are deemed highly reliable at 0.70 and above [27].

\subsection{Data analysis and interpretation}

In order to investigate the hypothesised relationships between the research variables, a multiple regression analysis was used to determine the effects of effectuation and TO (independent variables) on firm performance (dependent variable). However, as both effectuation and TO were treated as formative constructs, it was deemed necessary to perform multiple regression analysis using the underlying (level I) sub-constructs, and not the formative (level II) constructs [24]. Correlational significance was checked before embarking on the regression analysis using both level I and II constructs; thus the different dimensions of effectuation, TO, and performance are reported as well as their aggregate scores.

\section{RESULTS}

The sample characteristics indicate that just over half ( 51 per cent) of the firms had been established within the past three years, while 25 percent were between two and three years old, and 20 percent of the firms were 10 years or older. Around 40 per cent of the respondents had five years or less experience as an entrepreneur.

In terms of firm size, 35 per cent employed between two and five people, and 24 per cent employed six to 10 people. This places the majority of firms in the small business category according to the National Small Business Act [33]. The majority of firms in the sample were involved in installation (37 per cent) or distribution of RE products, while only a small 
number were involved in manufacturing (14 per cent) or research and development (6 per cent) of RE products.

\subsection{Descriptives and correlational analysis}

Descriptive statistics and correlations between the constructs are presented in Table 1 , where the Pearson correlation coefficients are reported; asterisks indicate the $p$-values. The descriptive statistics indicate a wide dispersion in the scores, with mean values ranging from 1.97 to 4.58 . Correspondingly, the standard deviations of most values exceed 1.00, suggesting high variation across the responses. Correlation coefficients also vary considerably, with several positive values that are statistically significant.

$\mathrm{H} 1$ posited noassociation between effectuation and TO. The results of the correlational analysis as presented in Table 1 indicate that several of the correlation coefficients are significant at both the level I (i.e. variables 1-10) and at the level II (i.e. variable 13 and 14) analysis. The relatively strong $(r>0.50)$ and positive correlations among the independent variables suggests that the unique variance they explain is limited, and it seems the variables are vulnerable to multicollinearity (correlations at 0.70 or more). This is addressed further in the next section when interpreting the regression analysis results [11]. This set of results allows for the rejection ofNull $\mathrm{H} 1$, considering the significant and positive association between effectuation and TO.

\subsection{Regression analysis}

Regression models were built for the next set of hypotheses. Furthermore each hypothesis was tested for the moderation effects of firm age, firm size and entrepreneurial experience. This necessitated three regression models for each of the sub hypotheses, resulting in a total of twelve regression models pertaining to $\mathrm{H} 2$ (due to space limitations only the most relevant regression results are shown).

The summary regression model reveals that the effectuation dimensions of precommitment, experimentation and flexibility impact significantly on the dependent variable (performance). The regression coefficients obtained for the different hypothesised effectuation dimensions are: experimentation $(\mathrm{H} 2 \mathrm{a})\left(\mathrm{R}^{2}=0.50, \mathrm{p}<0.05\right)$, pre-commitment $(\mathrm{H} 2 \mathrm{c})\left(\mathrm{R}^{2}=0.70, \mathrm{p}<0.05\right)$, and flexibility $(\mathrm{H} 2 \mathrm{~d})\left(\mathrm{R}^{2}=0.60, \mathrm{p}<0.05\right)$. The amount of variance that is explained by these independent variables means that the predictive and explanatory power of this model is relatively robust when examining the influence of effectuation on firm performance. Consequently, $\mathrm{H} 2$ may be rejected. To analyse further any control effects of effectuation on firm performance, principal component analysis was used to split the sample into two firm size groups: 'smaller firms' and 'larger firms'. The significance of pre-commitments as a predictor for firm performance was strongest when firm size was entered into the model as a control variable, whereas experimentation and flexibility did not contribute to the significance of their respective regression models. The regression output of the base model (pre-commitments vs performance), and the interaction variable (pre-commitments * size) are shown in Table 2, where both the base model and the model including size as a control variable were found to be significant.

Examination of the collinearity diagnostics reveals relatively medium-to-low variance proportions for the effectuation dimensions. These diagnostics - when read in conjunction with the collinearity statistics - indicate variable inflation factor (VIF) values between 0.533 and 0.332 . These figures are well below critical values and are deemed to be acceptable, indicating no incidence of multicollinearity. When the values are 10.0 or more, the regression coefficients can fluctuate widely from sample to sample, making it risky to interpret the coefficients as indicators of the predictors [11]. 


\begin{tabular}{|c|c|c|c|c|c|c|c|c|c|c|c|c|c|c|c|c|}
\hline & & 1 & 2 & 3 & 4 & 5 & 6 & 7 & 8 & 9 & 10 & 11 & 12 & 13 & 14 & 15 \\
\hline 1. & Experimentation & 1 & & & & & & & & & & & & & & \\
\hline 2. & Affordable loss & -0.18 & 1 & & & & & & & & & & & & & \\
\hline 3. & Flexibility & $0.39^{*}$ & -0.13 & 1 & & & & & & & & & & & & \\
\hline 4. & Pre commitments & $0.23^{*}$ & -0.11 & 0.2 & 1 & & & & & & & & & & & \\
\hline 5. & Pioneering & $0.34^{*}$ & 0.01 & 0.16 & $0.23^{*}$ & 1 & & & & & & & & & & \\
\hline 6. & Internal source & $0.26^{*}$ & 0.02 & -0 & 0.14 & $0.44^{*}$ & 1 & & & & & & & & & \\
\hline 7. & External source & $0.29^{*}$ & -0.17 & 0.16 & 0.18 & $0.27^{*}$ & $0.25^{*}$ & 1 & & & & & & & & \\
\hline 8. & $R \& D$ & $0.34^{*}$ & -0.06 & 0.07 & 0.18 & $0.47^{*}$ & $0.8^{*}$ & $0.75^{*}$ & 1 & & & & & & & \\
\hline 9. & Number of pProducts & $-0.24^{*}$ & -0.1 & -0 & 0.06 & $-0.44^{*}$ & $-0.47^{*}$ & -0.2 & $-0.40^{*}$ & 1 & & & & & & \\
\hline 10. & R\&D sSpending & -0.18 & -0.2 & -0.1 & -0.02 & $-0.27^{*}$ & -0.18 & 0.07 & -0.06 & $0.44^{*}$ & 1 & & & & & \\
\hline 11. & Performance objective & -0.19 & $-0.25^{*}$ & -0 & -0.013 & -0.14 & 0.09 & 0.1 & 0.01 & 0.17 & -0 & 1 & & & & \\
\hline 12. & Performance subjective & -0.03 & 0.09 & -0.2 & $-0.33^{*}$ & $-0.29^{*}$ & -0.05 & -0.2 & -0.16 & -0.02 & -0.2 & $0.51^{*}$ & 1 & & & \\
\hline 13. & Effectuation & $0.80^{*}$ & -0.22 & $0.65^{*}$ & $0.55^{*}$ & $0.31^{*}$ & 0.21 & $0.32^{*}$ & $0.31^{*}$ & -0.09 & -0.1 & -0.1 & -0.17 & 1 & & \\
\hline 14. & TO & $0.42^{*}$ & -0.05 & 0.15 & $0.26^{*}$ & $0.84^{*}$ & $0.73^{*}$ & $0.61^{*}$ & $0.86^{*}$ & $-0.50^{*}$ & -0.2 & -0.1 & $-0.28^{*}$ & $0.39^{*}$ & 1 & \\
\hline 15. & Performance & -0.13 & -0.08 & -0.1 & $-0.26^{*}$ & $-0.25^{*}$ & -0.07 & -0 & -0.07 & 0.05 & -0.2 & $0.86^{*}$ & $0.89^{*}$ & -0.2 & -0.2 & 1 \\
\hline \multicolumn{2}{|c|}{ Cronbach alpha } & 0.70 & 0.71 & 0.73 & 0.79 & 0.75 & 0.90 & 0.83 & 0.74 & 0.84 & 0.73 & 0.88 & 0.85 & 0.81 & 0.79 & \\
\hline \multicolumn{2}{|c|}{ Mean } & 2.71 & 4.04 & 1.99 & 2.65 & 3.02 & 4.31 & 4.38 & 4.35 & 3.29 & 2.95 & 4.58 & 4.13 & 2.47 & 3.69 & 4.28 \\
\hline \multicolumn{2}{|c|}{ Standard deviation } & 1.37 & 2.13 & 1.08 & 1.48 & 1.35 & 1.89 & 1.77 & 1.45 & 6.79 & 2.13 & 1.77 & 1.52 & 0.87 & 1.21 & 1.53 \\
\hline
\end{tabular}


Table 2: Regression model of pre-commitments and performance with firm size as control variable

\begin{tabular}{lllll}
\hline & Base model & & Incl. control & \\
Predictor & $\mathrm{B}$ & $\mathrm{p}$ & $\mathrm{B}$ & $\mathrm{p}$ \\
\hline Intercept & 2.497 & $*$ & 2.868 & \\
Pre-commitments & -0.703 & $*$ & -1.143 & \\
Size* pre-commitments & 1.711 & $*$ & 1.449 & \\
Pre-commitments *size & & & 0.310 & \\
\hline
\end{tabular}

\begin{tabular}{lll}
\hline$R^{2}$ base & 0.140 & \\
$\Delta R^{2}$ & 0.001 & \\
$F(2,65)$ base & 5.301 & $* *$ \\
$F(3,64)$ with control & 3.508 & $*$ \\
\hline \multicolumn{2}{c}{${ }^{*} p<0.05 ;{ }^{* *} p<0.001}$. &
\end{tabular}

\section{CONCLUSIONS}

This study contributes to the effectuation and technology literatures in several ways. First, it heeds the call of the literature [29] to transfer effectuation from its original field of conceptual research into the realm of empirical research. The study also provides modest insights into the practicalities of the quantitative analysis of effectuation and the problems that arise therein - in particular, issues surrounding measurement aspects [5]. Lastly, the study tests linkages between effectuation and TO, thereby acknowledging and examining performance differentials and increasingthe relevance of effectuation theory and TO. The findings of the present study agree favourably with past studies, which in terms of effectuation, by using the principles of experimentation, pre-commitments, and flexibility, can provide useful benefits for firm performance [48].

A deep and thorough understanding of effectuation and TO is important not only for academic purposes, but also because such an understanding is beneficial for both practitioners and policy-makers. The study emphasises the challenge and opportunity for firms in emerging economies to adopt a TO and act entrepreneurially in terms of effectuation, which can optimise and maximise performance. Reflecting on the study's findings and on insights gleaned from similar studies, it is recommended that policy makers review how they allocate funding to firms that have adopted a TO in the RE sector. Rather than focusing on business plans and financials, they should provide these firms with more latitude so that they can launch more innovations. This translates into encouraging TO firms to use effectual principles of experimentation and flexibility, establishing pre-commitments and alliances with a diverse set of multiple stakeholders, so as to constrain the potential losses [35].

Effectuation is relevant to emerging economies as it allows firms to experiment with a greater number of new ideas at lower costs. One major characteristic of firms in emerging markets is that established firms are being transformed into market-oriented enterprises. As the economy becomes more market-based, it is necessary for these reformed enterprises to undergo an entrepreneurial transformation at the organisational level in order to adapt to the transitioning institutional environment and to maintain competitiveness in both local and global markets. Effectuation as an internal organisational transformation and resource configuration mechanism may be a very important mediator that determines whether firms can realise the benefits derived from how they use technologies, resources, and networks [32]. Moreover, interrogating effectuation in the context of an emerging country allows 
researchers to compare and examine effectuation and TO in firms in similar environmental contexts.

Potentially, the study could offer guidance to strategic leaders in RE industries about the merits of pursuing effectuation and TO. The choice of RE is dependent not only on policy measures, but also on what type of RE sources are available to that specific country, what technologies exist, and the constraints that drive their deployment. As the RE sector competes with the traditional energy generation sector, technology and cost comparison both direct and indirect - inform the basis of many climate and clean energy practices. Energy is needed to power industry, especially in emerging and manufacturing based economies; and so energy cost is a major determinant of firm performance [21].

\subsection{Limitations and future research}

The results should be interpreted with caution because the study examined only one industry, thus raising questions about the generalisability of the findings. In addition, the study's cross-sectional nature neither permits causal inferences on the relationship between effectuation and TO on firm performance, nor allows inferences about long-term firm performance. Moreover, the study's measures of firm performance focused solely on financial criteria. Future studies could consider non-financial goals in evaluating firm performance to counteract such deficiencies. Due to the intermediate state of effectuation research and the methodology and scope limitations of this study, several suggestions can be made for future research in the field. These include the benefits of pursuing longitudinal studies, and expanding the sample frame across multiple industries to improve generalisability. Additionally, investigating the moderating effect of environmental uncertainty on the relationship between effectuation and performance could prove useful. Research would also be beneficialif focused on critical aspects of human and social capital that are compatible with emerging market demographics and institutions, considering that entrepreneurial ability is often allocated to non-productive ends in emerging economies.

\section{REFERENCES}

[1] Alegre, J.,Pla-Barber, J. Chiva, R. and Villar, C. 2012. Organisational learning capability, product innovation performance and export intensity, Technology Analysis and Strategic Management, Vol. 24, pp. 511-526.

[2] Aloini, D. and Martini, A. 2013. Exploring the exploratory search for innovation: a structural equation modelling test for practices and performance, International Journal of Technology Management, Vol. 61, pp. 23-46.

[3] Antonites, A.J. and Nonyane-Mathebula, B.T. 2012. Engineers as entrepreneurs: Entrepreneurial orientation of engineers in South Africa, South African Journal of Industrial Engineering, Vol. 23,pp. 1-17.

[4] Binneman, B. and Steyn, H. 2014.Criteria for selection and gate reviews of technology innovation projects. South African Journal of Industrial Engineering, Vol.25,pp. 117-130.

[5] Brettel, M., Engelen, A. and Küpper, D. 2011. Corporate effectuation: Entrepreneurial action and its impact on R\&D project performance, Journal of Business Venturing, Vol. 27, pp. 167-184.

[6] Brettel, M., Oswald, M. and Flatten, T. 2012. Alignment of market orientation and innovation as a success factor: A five-country study, Technology Analysis and Strategic Management, Vol. 24, pp. 151-165.

[7] Carmody, P. 2012. Another BRIC in the wall? South Africa's developmental impact and contradictory rise in Africa and beyond, European Journal of Development Research, Vol. 24, pp. 223-241.

[8] Chandler, G.N., DeTienne, D.R., McKelvie, A. and Mumford, T.V. 2011. Causation and effectuation processes: A validation study, Journal of Business Venturing, Vol. 26, pp. 375-390.

[9] Chen, J., He, Y.B. and Jin X. 2008. A study on the factors that influence the fitness between technology strategy and corporate strategy, International Journal of Innovation and Technology Management, Vol. 5, pp. 81-103.

[10] Clausen, T. and Korneliussen, T. 2012. The relationship between entrepreneurial orientation and speed to the market: The case of incubator firms in Norway, Technovation, Vol. 32, pp. 560567.

[11] Cooper, D.R. and Schindler, P.S. 2011.Business research methods(11 ${ }^{\text {th }}$ ed.), Boston: McGraw-Hill Irwin. 
[12] Covin, J.G. and Lumpkin, G. 2011. Entrepreneurial orientation theory and research: Reflections on a needed construct, Entrepreneurship Theory and Practice, Vol. 35, pp. 855-872.

[13] Davidsson, P. 2004.Researching entrepreneurship. International studies in entrepreneurship, New York: Springer.

[14] Del Brio, J.A. and Junquera, B. 2012. Towards sustainable competitive advantage by the innovation for the product value recovery: An empirical study in Spanish industrial companies, International Journal of Technology Management, Vol. 57, pp. 185-200.

[15] Dew, N., Read, S., Sarasvathy, S.D. and Wiltbank, R. 2008. Outlines of a behavioural theory of the entrepreneurial firm, Journal of Economic Behavior and Organization, Vol. 66, pp. 37-59.

[16] Dew, N., Read, S., Sarasvathy, S. and Wiltbank, R. 2009. Effectual versus predictive logics in entrepreneurial decision making: Differences between experts and novices, Journal of Business Venturing, Vol. 24, pp. 287-309.

[17] Eurostat. 2009. Panorama of energy. Energy statistics to support EU policies and solutions. Available from:http://epp.eurostat.ec.europa.eu/cache/ity_offub/ksgh-09-001/en/ks-gh-09-001en.pdf.

[18] Fisher, G. 2012. Effectuation, causation, and bricolage: A behavioural comparison of emerging theories in entrepreneurship research, Entrepreneurship Theory and Practice, Vol. 40, pp. 10191051.

[19] Galende J. 2006. Analysis of technological innovation from business economics, International Journal of Entrepreneurial Behaviour and Research, Vol. 11, pp. 25-41.

[20] Galbraith, C.S., Rodriquez, C.L.and De Noble,A.F. 2008. SME competitive strategy and location behaviour: An exploratory study of high-technology manufacturing,Journal of Small Business Management, Vol. 46, pp. 183-202.

[21] Grace, R.C., Rickerson, W.H. and Sawin, J.L. 2007. If the shoe fits: Using feeding tariffs to meet US renewable electricity targets, The Electricity Journal, Vol. 20, pp. 73-86.

[22] Hair, J., Black, W., Babin, B. and Anderson, R. 2010. Multivariate data analysis: A global perspective $\left(7^{\text {th }}\right.$ ed. $)$, New Jersey: Pearson.

[23] Kuratko, D.F. and Audretsch, D.B. 2009. Strategic entrepreneurship: Exploring different perspectives of an emerging concept, Entrepreneurship Theory and Practice, Vol. 25, pp. 1-17.

[24] MacKenzie, S.B., Podsakoff, P.M. and Jarvis, C.B. 2005. The problem of measurement model misspecification in behavioural and organizational research and some recommended solutions, Journal of Applied Psychology, Vol. 90, pp. 710-730.

[25] March, J.G. 1982. The technology of foolishness, in J.G. March (ed.), Ambiguity and choice in organizations (pp. 69-81). Bergen, Norway: Universitetsforlagetch.

[26] Mintzberg, H. 1994.The rise and fall of strategic planning: Reconceiving roles for planning, plans, planners. New York: Free Press.

[27] Nunnally, J.C. 1978. Psychometric theory ( $2^{\text {nd }}$ ed.), New York: McGraw-Hill.

[28] Park, S. and Bae, Z. 2004. New venture strategies in a developing country: Identifying a typology and examining growth patterns, Journal of Business Venturing, Vol. 19, pp. 81-105.

[29] Perry, J., Chandler, G. and Markova, G. 2011. Entrepreneurial effectuation: A review and suggestions for further research, Entrepreneurship Theory and Practice, Vol. 36, pp. 837-861.

[30] Podsakoff, P., Mackenzie, S., Lee, J. and Podsakoff, N. 2003. Common method biases in behavioural research: A critical review of the literature and recommended remedies, Journal of Applied Psychology, Vol. 88, pp. 879-903.

[31] Poon, J., Ainuddin, R. and Junit, S. 2006. Effects of self-concept traits and entrepreneurial orientation on firm performance, International Small Business Journal, Vol. 24, pp. 61-82.

[32] Read, S., Song, M. and Smit, W. 2009. A meta-analytic review of effectuation and venture performance, Journal of Business Venturing, Vol. 24, pp. 573-587.

[33] Republic of South Africa. 1996.Act No. 102 of 1996 (National Small Business Act). Pretoria: Government Publishers.

[34] Rosenbucsh, N., Brinckmann, J. and Bausch, A. 2011. Is innovation always beneficial? A metaanalysis of the relationship between innovation and performance in SMEs, Journal of Business Venturing, Vol. 26, pp. 411-457.

[35] Sarasvathy, S. 2001. Causation and effectuation: toward a theoretical shift from economic inevitability to entrepreneurial contingency, Academy of Management Review, Vol. 26, pp. 243263.

[36] Sarasvathy, S. 2008.Effectuation: Elements of entrepreneurial expertise, Cheltenham, UK: Edward Elgar Publishing Limited.

[37] Sarasvathy, S.D. and Venkataraman, S. 2011. Entrepreneurship as method: open questions for an entrepreneurial future, Entrepreneurship Theory and Practice, Vol. 35, pp. 113-135.

[38] Schindehutte, M., Morris, M.H. and Kocak, A. 2008. Understanding market-driving behaviour: The role of entrepreneurship, Journal of Small Business Management, Vol. 46, pp. 4-26.

[39] Schumpeter, J.A. 1934. The theory of economic development: An inquiry into profits, capital, credit, interest, and the business cycle. University of Illinois at Urbana-Champaign's Academy for Entrepreneurial Leadership Historical Research Reference in Entrepreneurship.

[40] Simon, H.A. 1996. Sciences of the artificial ( $3^{\text {rd }}$ ed. $)$, Cambridge, MA: MIT Press. 
[41] Steffens, P., Davidsson, P.P. and Fitzsimmons, J. 2009. Performance configurations over time: implications for growth- and profit-oriented strategies, Entrepreneurship Theory and Practice, Vol. 28, pp. 125-148.

[42] Steyn, J.L. and Buys, A.J. 2011. Creativity and 'eureka' in science and engineering.South African Journal of Industrial Engineering, Vol.22,pp. 1-17.

[43] Urban, B. and Barreira, J. 2009. Empirical investigations into firm technology orientation and entrepreneurial orientation, International Journal of Innovation and Technology Management, Vol. 7, pp. 1-23.

[44] von Broembsen, M., Wood, E. and Herrington M. 2005.Global entrepreneurship monitor, South African Report 2005. Cape Town: Graduate School of Business, University of Cape Town.

[45] Wang, X., Lu, Y., Zhao, Y., Gong, S. and Li, B. 2013. Organisational unlearning, organisational flexibility and innovation capability: An empirical study of SMEs in China, International Journal of Technology Management, Vol. 61, pp. 132-155.

[46] Wiklund, J. 1999. The sustainability of the entrepreneurial orientation-performance relationship, Entrepreneurship Theory and Practice, Vol. 21, pp. 635-657.

[47] Wiklund, J. and Shepherd, D. 2003. Knowledge-based resources, entrepreneurial orientation and the performance of small and medium sized businesses, Strategic Management Journal, Vol. 24, pp. 1307-1314.

[48] Wiltbank, R., Dew, N., Read, S. and Sarasvathy, S.D. 2006. What to do next? The case for nonpredictive strategy, Strategic Management Journal, Vol. 27, pp. 981-998.

[49] Yim-Teo, T.H. and Chao, C.T.C. 2004. Embodying corporate entrepreneurship in strategic entrepreneurship for technology firms, International Journal of Innovation and Technology Management, Vol. 1, pp. 185-198.

[50] Zahra, S.A. 1996a. Technology strategy and financial performance: Examining the moderating role of the firm's competitive environment, Journal of Business Venturing, Vol. 11, pp. 189-219.

[51] Zahra, S.A. 1996b. Technology strategy and new venture performance: A study of corporatesponsored and independent biotechnology ventures, Journal of Business Venturing, Vol. 11, pp. 2.

[52] Zahra, S. A. and Covin, J. G. 1993 'Business strategy, technology policy and firm performance', Strategic Management Journal, Vol. 14, pp. 451-478. 